Journal of Educational

Technology \& Online Learning

Volume 4 | Issue 4 | 2021

http://dergipark.org.tr/jetol

\title{
An investigation of the integration of blogs into EFL classes: Learners' views toward blogs and preferences for writing classes
}

\author{
Samet BAL ${ }^{\text {* }}$ (D) \\ a Yildiz Technical University, Turkey \\ Suggested citation: Bal, S. (2021). An investigation of the integration of blogs into EFL classes: Learners' views toward blogs and \\ preferences for writing classes. Journal of Educational Technology \& Online Learning, 4(4), 594-604.
}

\begin{tabular}{ll}
\hline Article Info & Abstract \\
\cline { 2 - 3 } $\begin{array}{l}\text { Keywords: } \\
\text { Writing skills }\end{array}$ & $\begin{array}{l}\text { Writing is especially considered to be a difficult language skill to master for beginner } \\
\text { learners. However, this century offers innovations in language education through } \\
\text { Blogs }\end{array}$ \\
$\begin{array}{l}\text { Information and Communication Technology tools. For instance, blogging platforms like } \\
\text { Tumblr, Blogger, and WordPress can be employed in writing classes. At this point, the } \\
\text { EFL learners } \\
\text { pechnology in education. }\end{array}$ & $\begin{array}{l}\text { Language learners after they practiced their writing skills with blogs for eight weeks. } \\
\text { The research utilized WordPress blogs, and a group of } 28 \text { learners attended the study. } \\
\text { These students were supposed to start a blog and write an essay each week on their blogs. } \\
\text { The research was designed as a qualitative exploratory case study. To collect the data, } \\
\text { semi-structured interviews with ten randomly chosen learners were conducted to } \\
\text { understand their views toward blogs and preferences for writing classes at the end of the } \\
\text { treatment. The content analysis method was instrumented to analyze the qualitative data } \\
\text { inductively; thus, the data was first coded, and themes emerged. Unlike the previous } \\
\text { studies in the field, these findings have revealed the learners' views towards their self- } \\
\text { confidence, digital literacy, and writing habits, which changed in a positive manner. } \\
\text { Besides, it was also understood that the participants made their preferences in favor of } \\
\text { blogs rather than paper-based activities. }\end{array}$ \\
\hline Research Article &
\end{tabular}

\section{Introduction}

Writing, as a productive skill, necessitates EFL learners to produce output in the target language. However, learners rarely produce excellent works for which they should make much effort as they usually think that meeting the minimum expectations to pass a class is enough for them. As a result, a teacher cannot make them produce competitive and challenging works and has to give feedback for some assignments delivered after a simple process involving a pen, a paper, and some paragraphs meeting lower limit expectations (Roy, 2016).

To overcome this significant problem that teachers may experience in an EFL classroom setting, teachers should look for some alternative ways for EFL learners to complete their writing tasks in a relatively challenging and productive way rather than submitting the tasks with the assumption that meeting lower limit expectations is enough to succeed in that class. At this point, Uzun (2017) claims that the teaching process has started to lose its power while the learning process has become much more creative and innovative. One of the innovative ways that can be implemented in classrooms is the utilization of blogs,

\footnotetext{
* Corresponding author: School of Foreign Languages, Yildiz Technical University, Turkey.

e-mail address: samettbal@gmail.com

This study was partly presented as a proceeding at the 1st International Conference on Educational Technology and Online Learning Conference held between 22-24 September 2021.
} 
which have been defined in similar ways by different researchers. For instance, Goodwin and Jones (2003) stated that a blog is a web space where editing and writing are achieved through a web browser and produce works visible to the public, while Zhang (2009) stated that blogs are professional or personal journals often updated and intended for public consumption. The journal form, style, and opportunity to publish a post every day are some of the basic features of blogs. Plus, most blogs let you publish videos, audio, and photos (p. 65). In my opinion, blogs can be used for specific aims (educational, business, or to introduce a product, service, or individual) by offering users simplified interfaces that let them administer their space on the internet. On these blogs, students can share their views, works, and thoughts without facing real-life restrictions, such as hesitancy to speak out or embarrassment to express themselves. Therefore, blogs as a Web 2.0 tool can help language teachers in writing classes in different aspects. They can, for instance, enable teachers to create an atmosphere that can stimulate not only interactions and collaboration among learners but also creativity. Furthermore, it can be claimed that these Web 2.0 tools give students the chance to be more productive and creative in the language learning process since they trigger interactions and collaboration and are greatly adaptable thanks to the enrichment with multimedia, accessibility from anywhere, interaction with other readers or writers unlike Web 1.0 tools; for example, traditional webpages or e-mails can neither offer interactions or collaboration among language learners (Harrison \& Thomas, 2009; Pegrum, 2009). Thus, blogs are considered one of the best Web 2.0 tools to use in language classes (Tu, Blocher \& Ntoruru, 2008).

Moreover, Blogs, as free, basic Web 2.0 tools, allow learners to share their ideas on an online platform and publish them on the internet (Bloch, 2007, p. 128). In addition, blogs can not only foster constructivist learning strategies (Gresham et al., 2012, p. 44) but also help learners of today's digital world improve their digital literacy and become relatively more digitally competent. Besides, bloggers can express their views readily without facing any traditional classroom problems or difficulties, such as looking for an eraser, pen, or new sheet of paper since they can edit their work by simply clicking on a button, all the while respecting the conditions that a traditional classroom can offer. Furthermore, they are more likely to feel free to express themselves and write on their blogs without hesitating due to the fear of facing some objections from their classmates, which could prevent them from speaking out in a classroom. Besides, EFL students can develop their language skills with blogs since they will be required to use some new words and take responsibility for their writing tasks, which can help them become autonomous language learners for the rest of their lives (Pinkman, 2005). Besides, blogs, with their various features, are smoothly combined with the classes. Thus, learners can start their own blogs, complete the assignments, and submit the link to the teacher.

Considering all these advantages, language teachers should start learning more about how to integrate their classes with Web 2.0 tools and Information and Communication Technology (ICT) tools, like blogs. Indeed, each teacher expects to see a competitive or collaborative atmosphere, which has been created by methods and techniques instrumented in the classroom and encourages learners to complete their tasks by performing their best and reflecting their creativeness. Many studies in the field have also investigated the effects of blogs on EFL learners (Hashemi \& Najafi, 2011; Amir, Ismail, \& Hussein, 2011; Yunus et al., 2013; Wang \& Vásquez, 2014; Jin, 2015; Roy, 2016) and shown that blogs help language learners perform better at the target language skills and improve their vocabulary and grammar as a consequence of looking for vocabulary, phrases, and structures to be able to clearly express their views (Hashemi, Najafi, 2011; Yunus et al., 2013). However, there are still some gaps in the literature as few studies investigated EFL learners' views toward blogs through interviews and the evaluation of the qualitative aspect after a long treatment period. The present research aims to contribute to the literature and further reshape teachers' practices in the classroom through the 8-week treatment with 28 EFL learners.

\section{Literature}

Language skills are classified under two categories; listening and reading are identified as receptive skills, while reading and speaking are identified as productive skills (Harmer, 2007). Compared to the other main 
skills, writing requires relatively more systematic effort to be produced efficiently. It indeed necessitates mental processes in which EFL learners are supposed to share their ideas, views, and comments in order; reflect them on a paper or platform considering the punctuation, grammar, and linguistics rules; and have both vocabulary and grammar knowledge to express themselves. In other words, writing makes learners' brains, eyes, and hands function in a cooperative way (Hamid, 2011).

The importance of writing should not be underestimated since learners need to improve their writing skills, as well as other skills, to master the target language and function both in official and unofficial contexts. However, writing is generally regarded as a difficult skill to master, particularly for beginner learners (Boscolo \& Hidi, 2007). The reason may be that writing, contrary to other skills, requires learners to plan their ideas and organize them before reflecting them on paper. Furthermore, they may need to look up some words, check grammar rules, check dictionaries for punctuation, or some other sources to look for alternatives in their works (Harmer, 2004). Besides, the fact that learners do not need to master their writing skills until they attend a school may be another reason for that view, as stated in Javed, Juan, and Nazli (2013) 's study, as students start to communicate in written forms when they start to interact with people at school. Additionally, someone who is acquiring their first language skills makes use of listening and speaking until they begin to produce systematic language writings at schools, which makes writing seem unnatural and challenging for them (Raimes, 1983).

Krashen and Lee (2004) have claimed that a person becomes cleverer thanks to writing since writing requires the writer to use their brain effectively and actively to find out suitable structures, words, and phrases to organize their ideas and thoughts. Thus, many methods and techniques have been offered or implemented by researchers to assist learners in becoming proficient writers. Some of them are free writing, creative writing, process-oriented writing, and product-oriented writing, to name a few. These various approaches and methods all have a single common aim: to help learners improve their writing skills, although each method prioritizes different aspects. For example, free writing fosters writing for communicative purposes by prioritizing fluency and does not focus on grammar rules, while productoriented writing regards vocabulary and grammar rules as significant aspects in writing (Scott, 1996).

At this point, Uzun (2017) states teachers should utilize innovative methods for digital native students. Therefore, we can claim that teachers should take learners' needs and interests into account and choose the most appropriate method to apply in EFL classes because, if the instruction of writing skills fails in the classroom, learners' performance may be affected negatively. Consequently, some of them are likely to change their views toward these classes, and their aptitude level may decrease.

\subsection{Technology and Writing}

In this century, the methods and approaches of writing can be supported by internet technologies as those offer simplicity, creativity, flexibility, and surely, modernity, which completely contrasts with traditional classrooms. It should not be forgotten that today's learners are familiar with technology as they rely on it in every field of life. Wilber $(2010$, p. 9) states that

\section{"Every day, when I walk from my car to my office on campus, I see students all around me immersed in technology. Many are using their cell phones, not to talk but to text each other ... Most of the students in the study lounges I pass are working on their laptops. Since our campus is wireless, they are doing anything from coursework to checking their Facebook page."}

Unsurprisingly, learners are very likely to spend hours on their cellphones and computers. At this point, Similarly, Hutchison \& Wang (2012) state that it has become ordinary and common for learners to spend time playing games, chatting, surfing, and listening to music on a computer or cellphone. They spend a lot of time on those kinds of technological devices. Hyland (2008) states that "in a world increasingly dominated by electronic Information and Communication Technologies (ICT), it is unsurprising that writing teachers are often faced with demands to integrate these technologies into their classes" (p. 144). 
Therefore, it is clearly seen that digital native learners may have different demands that will meet their needs in accordance with the modern-day world technology and opportunities offered to them in their lives.

Taking these statements from previous studies into consideration, teachers can be advised to integrate and improve writing skill classes with the tools offered by technology. In this way, they will be able to keep up with today's world facts and update their classes by regarding these opportunities and learners' needs and habits daily. Similarly, Hyland (2008) and Stapleton (2010) stated that ICT tools greatly influence the writing process, which is why the instruction of writing should benefit from computer and internet technologies as those can affect learners' writings, blogging thus could be put forward as one of the Web 2.0 and ICT tools that can be integrated into writing classes. However, when it comes to the obligatory technology integration process as it was seen in the Covid pandemic days, the process should be carefully implemented since it may lead to a negative impact on the motivation of learners due to the mismatch among the factors such as organizational problems, the learning environments, expectations, and content (Meşe \& Sevilen, 2021); at this point, students can be encouraged and educated to be a good digital citizen (Öztürk, 2021) as they can become someone who use digital tools to cooperate with other people; care about physical, emotional and mental health; utilize technology to support and develop social goals (ISTE, 2018).

\subsection{Previous Research}

There have been early studies on blogs and EFL learners with different findings. For instance, these studies pointed out that EFL learners have positive attitudes and experiences with blogs (Tu, Chen, \& Lee, 2007), the blogs could enhance learners' motivation and trigger their autonomy (Sun, 2010; Taki \& Fardafshari, 2012), besides, blogs play an important role in individual, social, and academic dimensions (Yuen, Deng, 2012) and they could encourage students to perform actively and reflectively in knowledge sharing and knowledge generation and could also help with the development of various strategies to deal with problems occurring throughout the writing process and reward students with a sense of authorship (Sun, Chang, 2012), blogs not only affect learners' writing skills but also arouse their curiosity (Koçoğlu, 2009), and finally, they had a great potential to improve learners' writing skills (Arslan, Şahin-Kızıl, 2010).

More research on blogs has also been conducted in the current decade with different purposes. These studies also showed that blogs enhance EFL learners' writing skills in specific tasks and promote collaboration (Vurdien, 2013); blogs and essays best function as complementary writing tasks since both promote learners writing and research skills (Hansen, 2016). Besides, Yakut and Aydin (2017) investigated the effects of blogs on reading comprehension achievement, which was hardly ever studied before. However, the researchers reported that blogs do not ensure the improvement of EFL learners' comprehension skills. Sütçü (2020) also studied blogging and academic writing, and his research indicated that blogging enhances learners' writing skills, and a significant increase in the scores of these students was observed. With regards to the previous research, it can be claimed that no research has solely focused on the views of EFL learners and asked them their preferences in comparison to paper-based writing activities, which makes this research novel and unique as the previous research generally focused on achievement levels, motivation and evaluated their writing skills.

\subsection{Research Questions}

The present research seeks answers to the following research questions, with the aim of understanding the effects of blogs on EFL learners, as well as their views toward blogs at the end of the treatment.

1. What are EFL learners' views toward blogs after the treatment?

2. What are EFL learners' preferences in terms of writing classes at the end of the treatment? 


\section{Methodology}

The present research, built upon the constructivist paradigm in which the researcher tries to understand participants' experiences from their point of view as they are the ones who experienced the process (Schwandt, 2000), was designed as an exploratory case study aiming to understand EFL learners' views and preferences at the end of the treatment. For that, we used semi-structured interviews to explore a phenomenon in context by gathering data with one or more tools (Creswell, 2013). This study involved 28 EFL learners who were enrolled in the engineering department of a state university and were attending intermediate English classes. Ten of these participants were invited to take part in interviews at the end of the treatment.

\subsection{Data Collection Tools}

All students were first asked to start their own blogs — a procedure introduced by the researcher. There are many alternatives when it comes to starting a free blog, such as blogger.com, blogcu.com, wordpress.com, tumblr.com, and more. Once all the alternatives were analyzed, it was detected that the most suitable platform for educational purposes was WordPress as it came with no cost, limited ads, many features, and a functional panel, which offered learners some freedom in terms of themes, writing styles, domain name, and offered privacy for learners who wanted to hide their posts or set a password for a specific post. Therefore, the group utilized WordPress blogs. The study implemented semi-structured interviews to collect the data to answer the research questions at the end of the treatment with 10 participants who were chosen using the random sampling method (Creswell, 2012). Therefore, every other student on the class's registered student list was invited to the interviews. "A pre-prepared, elaborate interview schedule/guide" (Dörnyei, 2007, p. 135) has been followed for the format of interviews, which requires a particular set of questions to be addressed with each interviewee to make it possible for the researcher to compare the data across all the participants.

1. Do you think that blogs affect your writing skills? If yes, how?

2. What are the advantages and disadvantages of blogs for you?

3. Do you practice writing in another way than through blogging? If yes, how?

4. Do you prefer to write an essay on a blog or on paper? Why?

\subsection{Data Collecting Procedures}

The students were required to write a 225 -to-250-word essay in 45 minutes at the computer lab. They were explained that they were supposed to write an essay and that the evaluation criteria were shared and explained to them to prevent a probable disappointment in the future. Furthermore, the teacher followed all of the learners' blogs using his own account to get notified whenever their works were published. While the students were writing their essays, the teacher wandered around the computer lab to help those who needed help to overcome the problems they could experience, both technically and linguistically. Twenty-eight students in the group started their blogs on WordPress and practiced writing for eight weeks by typing out essays on the topics that were shared on their teacher's blog. At the end of the treatment, semi-structured interviews were held with ten students. As previously explained, these students were randomly selected and kindly asked to participate in the interviews. The above-mentioned questions were addressed with the interviewees to understand their views and beliefs toward blogs. Each interview took approximately 15 minutes. The answers were recorded by a smartphone, and students were notified of this procedure.

\subsection{Reliability and Validity of the Data}

The data were coded by two experts, they then worked on these codes, and the themes emerged from the data; apart from that, the interviewers' notes and the recordings of the interview sessions were utilized to increase the reliability by eliminating any personal and methodological biases, and validity of the data set with by ensuring findings clearly reflect the data (Noble \& Smith, 2015) 


\subsection{Data Analysis}

The qualitative data gathered through the interviews were analyzed through the content analysis method, which aims to reveal thematic patterns from the data (Neuendorf \& Kumar, 2015). The researcher and a colleague, who had his master's degree in English Language Education program, rigorously analyzed the data and applied the open coding firstly, and process coding and descriptive coding were performed for some statements of the learners (Flick, 2009) as the coding procedure enabled the researchers to regroup similar codes, then, these codes were placed under different themes whose numbers varied from one question to another.

\section{Findings}

\subsection{Views of EFL Learners}

The first and second interview questions were asked to answer the first research question, which seeks to understand EFL learners' views toward the use of blogs in writing classes. Therefore, the answers to the question "Do you think that blogs affect your writing skills? If yes, how?" were first coded. Then, these codes were placed under the emerging themes (Table 5). This question's purpose was to understand learners' views toward the efficiency of blogs. Surprisingly, all the participants stated that they believed blogs helped them improve their writing skills; however, what makes writing on blogs is unique can be understood in the next statements of these learners as they stated that they felt more confident in language classes and blogs made writing attractive.

\section{Table 1.}

Do you think that blogs affect your writing skills? If yes, how?

\begin{tabular}{lll}
\hline Themes & Codes & N \\
\hline Language skills & It is a chance to practice the target language. & 7 \\
& Blogging enhances vocabulary learning. & 6 \\
& It contributes to grammar learning. & 3 \\
Cognitive skills & It makes me think in English. & 3 \\
& It enables creative thinking. & 1 \\
& I felt more confident in language classes. & 4 \\
& It makes writing attractive. & 2 \\
& It turns writing into a habit. & 1 \\
\hline
\end{tabular}

Following the first answers, they were asked why they thought blogs helped them. The most frequent statements were related to practicing the target language, learning vocabulary, and feeling self-confident. For example, one interviewee stated that "While writing the posts, I learned new vocabulary because the words that I know did not meet my needs ... I used dictionaries and translation tools, and it was all about practicing the language for me." The findings of this question show that EFL learners believe blogs enable them to practice the target language, help them learn new words and use them, and, particularly, make them feel capable of using the target language, which makes them feel self-confident. Some of the interviewees stated that blogs helped them improve their writing skills in different ways. For instance, they believed they enabled them to think in English while using the target language. They also made the writing process attractive, which turned into a habit over time. Besides, one interviewee stated that "[blogs] helped [them] to think in a creative way since producing the target language and meeting the expectations of the teacher 
may be challenging from time to time for [students]." All in all, these results point out that blogs can be utilized to enhance learners' cognitive skills, in addition to their language skills, in EFL classrooms.

The next question was, "What are the advantages and disadvantages of blogs for you?" and the codes and the themes given in the next table (Table 2), which aimed to clarify EFL learners' views toward blogs at the end of the treatment. Many interviewees stated that they believed blogs were advantageous $(\mathrm{N}=8)$, although some of them stated they had some disadvantages and advantages $(\mathrm{N}=2)$. For instance, one interviewee stated, "I can make use of other online tools such as Thesaurus to look for synonyms, and Cambridge Dictionary to understand how to use that word in a sentence." Additionally, another one said, "I really get bored when I have to write something on a paper ... But in the computer lab, writing becomes attractive, and I can embed some videos and visuals to my post." On the other hand, one interviewee who reported positive views on blogs also claimed, "I have seen some friends while they were copying some sentences from other websites to compete with us. I think they deceived themselves, but this may be regarded as a disadvantage." However, none of them claimed that blogs were solely disadvantageous.

\section{Table 2.}

What are the advantages and disadvantages of blogs for you?

\begin{tabular}{lll}
\hline Themes & Codes & N \\
\hline \multirow{2}{*}{ Writing online is attractive. } & 4 \\
& It is competitive. & 3 \\
& It enhances digital literacy. & 2 \\
& Benefitting from online tools is possible. & 6 \\
& It is free to write. & 2 \\
& Embedding visuals in posts is doable. & 4 \\
& Posts are public. & 4 \\
& It is easy to access thanks to the internet. & 3 \\
& I can edit the post later if necessary. & 4 \\
& I can self-evaluate and compare. & 5 \\
\hline Disadvantages of blogs & Translation tools are usable. & 1 \\
& Internet connection sometimes fails. & 1 \\
& Plagiarism is possible. & 1 \\
\hline
\end{tabular}

As it can be inferred from interviewees' answers, blogs are regarded as advantageous as they enable EFL learners to make use of internet tools and post their essays easily. Furthermore, they can be visited by everyone and accessed easily by writers themselves, as well as other people. The interviewees believe that blogs are attractive since they can enrich their posts with visuals and videos to support their works. Plus, they make it easy for them to edit an essay compared to paper-based writing activities. Moreover, some learners like that they can compare their current works with their previous ones to see how much progress they made and evaluate their achievements $(\mathrm{N}=5)$.

On the contrary, some interviewees mentioned some disadvantages as writing essays on blogs at computer labs could offer some opportunities for learners to cheat. For example, one interviewee stated that "translating a passage from Turkish to English is doable within seconds." Another one reported that "plagiarizing some other essays on other websites could be done without teachers noticing." One of them 
also stated that the internet connection sometimes failed, which surely was a disadvantage. At this point, we can understand that learners can take advantage of various opportunities thanks to an internet connection and may try to deceive teachers. For this reason, teachers should wander around the computer lab to monitor the learners in order to make them feel like they are being followed. Furthermore, they could check students' works through plagiarism checkers, such as turnitin.com, to ensure the uniqueness of the essays published on the blogs.

\subsection{Learners' Preferences}

The next two interview questions were designed to offer data for the second research question, which aimed to investigate EFL learners' preferences for writing classes and whether the treatment affected their choices or not. The third interview question was "Do you practice writing except blogging? If yes, how?" and aimed to find out whether students applied any other methods or techniques besides the blogs on which they were required to write an essay each week over the last eight weeks to improve their writing skills. One of the interviewees stated, "I believe I already do much in terms of writing practice. I do not feel it is necessary to practice writing apart from blogs." Another interviewee also claimed, "I just use my blog, and even after the classes finish, I will use my blog as a personal diary ... I will write about the places I visit and the books I read." Through similar statements, all of the participants reported that they had no other techniques to practice their writing skills. All in all, on the one hand, EFL learners did not practice writing skills outside the classroom. They just made use of blogs and believed that blogging would be enough to help them master their writing skills. On the other hand, we can thus state that EFL teachers should not assume the learners would practice their writing skills unless they are told to do so.

\section{Table 3.}

Do you prefer to write an essay on a blog or on paper?

\begin{tabular}{ll}
\hline \multicolumn{1}{c}{ Preferences } & $\mathrm{N}$ \\
\hline I prefer writing on blogs. & 9 \\
I prefer writing on both blogs and paper. & 1 \\
\hline
\end{tabular}

After the interviewees shared their views on the advantages and disadvantages of blogs, the researcher aimed to disclose their final choice between blogs or paper-based writing activities. Therefore, the following question, "Do you prefer to write an essay on a blog or on a paper? Why or why not?" was asked to understand ESL learners' preferences (Table 3). It was seen that all of the interviewees wanted to use blogs in their writing classes. For instance, one interviewee said, "I did not think blogs would be that much easier for me to publish a post and edit it later if necessary. For sure, I want to go on writing exercises with my blog." Another one stated, "Blogs are easy to access, and my friends can also see my posts. I like writing in this way as it becomes public and stays there forever. On the contrary, I can easily lose my essays on paper." Despite these positive views on blogs, one interviewee pointed out a negative aspect of blogs by stating that "we also need to practice on a paper since we will not use blogs in a real life exam and we should also be fast and well organized while we write essays on a paper." These findings indicate that the EFL learners who made use of blogs for eight weeks were still willing to practice their writing skills through an ICT tool rather than paper-based activities. Besides, we can claim that interviewees were really affected by the advantages that blogs offer to them. Thus, they did not hesitate on which method to choose to practice their writing skills. 


\section{Discussion and Conclusion}

Firstly, it should be noted that the present study is one of the rare studies that investigated EFL learners' views toward the use of blogs and their preferences for writing classes and has reached some unique findings. Regarding learners' views, we can claim that blogs should not only be evaluated in terms of the scores learners get as they have some other crucial effects on learners. At this point, some previous studies have indicated that blogs enhance motivation and trigger learners' autonomy (Tak \& Fardafshari, 2012); encourage them to perform actively and reflectively in knowledge sharing (Sun and Chang, 2012) and promote collaboration (Vurdien, 2013). Accordingly, the present study has also found some positive effects reported by learners. For instance, it has been understood that blogs helped them build self-confidence, contributed to their grammar and vocabulary learning, enabled them to think in English, and turned the writing process into an attractive process. Besides, the majority of ESL students also reported that blog assignments helped them practice the target language. Overall, all these opportunities are understood to enable them to have positive views toward blogs. In this aspect, the present study aligns with one of the early studies conducted by Tu, Chen, and Lee (2007), which again revealed learners' positive attitudes toward blogs.

When it comes to the second research question, the study has found that all of the participants preferred blogs to paper-based writing activities for the various reasons they listed as advantages. For instance, they reported that writing online is attractive and that their digital literacies had been positively affected since they started benefiting from various online tools and websites. They performed the writing tasks for months on WordPress, a blogging platform, and have become capable of starting a blog, publishing a public post, and using audiovisual materials in their essays. Furthermore, learners can compare their most recent essays with previous ones and write well-established essays compared to previous works thanks to the feedback provided by the teacher.

Finally, the present study indicated some significant results of the integration of blogs into writing classes that had not been reported before, as it has revealed the views of EFL learners in terms of whether blogs affect their digital literacy skills and help them improve their creative thinking skills and self-confidence. Besides, few studies conducted interviews to compare paper-based writing activities with blogs. At this point, it has been understood that learners definitely favor blogs over paper-written essays if presented with a choice. Considering all these reasons, we can conclude that EFL teachers should abandon traditional teaching methods for digital native students (Uzun, 2017); in other words, teachers should not insist on traditional teaching methods for digital native students as they may perform better if this opportunity is given to them. The teachers should also consider the positive views that learners build toward ICT tools and enable them to improve their language skills with the help of such tools. However, the present research also encountered a limitation; further research could be conducted with a bigger sample and may direct additional questions to investigate the issues to a better extent.

\section{References}

Abidin, M. J. Z., Pour-Mohammadi, M., \& Hamid, F. B. A. (2011). Blogging: promoting peer collaboration in writing. International Journal of Business, Humanities and Technology, Vol. 1, No. 3, 98-105.

Amir, Z., Ismail, K., \& Hussein, S. (2011). Blogs in language learning: Maximizing students' collaborative writing. Procedia-Social and Behavioral Sciences, 18, 537-543.

Arslan, R. Ş., \& Şahin-Kızıl, A. (2010). How can the use of blog software facilitate the writing process of English language learners? Computer Assisted Language Learning, 23(3), 183-197.

Bloch, J. (2007). Abdullah's blogging: A generation 1.5 student enters the blogosphere. Language Learning and Technology, Volume 11, Number 2, 128-141. 
Boscolo, P., \& Hidi, S. (2007). The multiple meanings of motivation to write. In S. Hidi \& P. Boscolo (Eds.), Writing and motivation (pp.1-16). Elsevier.

Creswell, J. W. (2012). Educational research: Planning, conducting, and evaluating quantitative and qualitative research. Pearson Education.

Creswell, J. W. (2013). Qualitative inquiry \& research design: Choosing among five approaches. (3rd ed.). Sage.

Creswell, J. W., Plano Clark, V. L., Gutmann, M., \& Hanson, W. (2003). Advanced mixed methods research designs. In A. Tashakkori \& C. Teddlie (Eds.), Handbook of mixed methods in social and behavioral research (pp. 209-240). Sage.

Deng, L., \& Yuen, H. K. (2012). Understanding student perceptions and motivation towards academic blogs: An exploratory study. Australasian Journal of Educational Technology, 28(1), 48-66.

Dörnyei, Z. (2007). Research methods in applied linguistics. Oxford University.

Flick, U. (2009). An introduction to qualitative research (4th ed.). Sage.

Gresham, J., Carlson Bowles, B., Gibson, M., Robinson, K., Farris, M., \& Felts, J. (2012). "Deathplanning for the inevitable: a hybrid honors course". Honors in Practice, Online Archive, 159. https://digitalcommons.unl.edu/nchchip/159

Hansen, Holley. (2015). The Impact of Blog-Style Writing on Student Learning Outcomes: A Pilot Study. Journal of Political Science Education. 12. 1-17. 10.1080/15512169.2015.1060887.

Harrison, R., \& Thomas, M. (2009). Identity in online communities: social networking sites and language learning. International Journal of Emerging Technologies and Society, 7(2), 109-124.

Hashemi, M., \& Najafi, V. (2011). Using blogs in English language writing classes. International Journal of Academic Research, 3 (4), 599 - 604.

Hutchison, A., \& Wang, W. (2012). Blogging within a social networking site as a form of literature response in a teacher education course. Educational Media International, 49(4), 263-275.

Hyland, K. (2008) Second Language Writing (5th edition). Cambridge University Press.

International Society for Technology in Education [ISTE] (2018). Citizenship in the digital age. Retrieved from https://elearninginfographics.com/citizenship-digital-age-infographic/

Javed, M., Juan, W. X., \& Nazli, S. (2013). A Study of students' assessment in writing skills of the English language. International Journal of Instruction.

Jin, S. (2015). Using Facebook to promote Korean EFL learners' intercultural competence. Language, Learning \& Technology, 19(3), 38-51.

Koçoğlu, Z. (2009). Weblog use in EFL writing class. Ankara University Journal of Faculty of Educational Sciences, 42(1), 311-327.

Krashen, S., \& Lee, S. Y. (2004). Competence in foreign language writing: Progress and lacunae. Literacy across Cultures, 12(2), 10-14.

Meşe, E. \& Sevilen, Ç. (2021). Factors influencing EFL students' motivation in online learning: A qualitative case study. Journal of Educational Technology \& Online Learning, 4(1), 11-22.

Noble, H. \& Smith, J. (2015). Issues of validity and reliability in qualitative research. Evidence-based Nursing, 18(2), 34-35.

Öztürk, G. (2021). Digital citizenship and its teaching: A literature review. Journal of Educational Technology \& Online Learning, 4(1), 31-45. 
Pegrum, M. (2009). Communicative networking and linguistic mashups on Web 2.0. In M. Thomas (Ed.), Handbook of research on Web 2.0 and second language learning (pp. 20-41). IGI Global.

Pinkman, K. (2005). Using blogs in the foreign classroom: Encouraging learner independence. JALT CALL Journal, 1(1), 12-24.

Raimes, A. (1983). Techniques in teaching writing. Oxford University Press.

Roy, C. K. (2016). Be creative and collaborative: strategies and implications of blogging in EFL classes. English Language Teaching, Vol. 9, No. 7, Canadian Center of Science and Education.

Schwandt, T. A. (2000). Three epistemological stances for qualitative inquiry: Interpretivism, hermeneutics, and social constructionism. In N. K. Denzin \& Y. S. Lincoln (Eds.), Handbook of qualitative research (2nd ed., pp. 189-214). SAGE.

Scott, V. M. (1996). Rethinking Foreign Language Writing. Heinle \& Heinle Publishers.

Stapleton, P. (2010). Writing in an electronic age: A case study of L2 composing processes. Journal of English for Academic Purposes, 9, 295-307.

Sun, Y. C. (2010). Extensive writing in foreign-language classrooms: A blogging approach. Innovations in Education and Teaching International, 47(3), 327-339.

Sutcu, S. (2020). Blogging in EFL Learners' Academic Writing. International Journal of Progressive Education, 16(6), 344-351. doi: 10.29329/ijpe.2020.280.21

Taki, S., \& Fardafshari, E. (2012). Weblog-based collaborative learning: Iranian EFL learners' writing skill and motivation. International Journal of Linguistics, 4(2), 412-429.

Tu, C. C., Chen, P. C., \& Lee, M. Y. (2007). Fostering EFL learners' writing competence through webbased guided writing. An Interdisciplinary Journal, 53, 225-244.

Tu, C., Blocher, M., \& Ntoruru, G. (2008). Constructs for Web 2.0 learning environments: A theatrical metaphor. Educational Media International, 45(4), 253-269. doi: 10.1080/09523980802588576

Uzun, L. (2016). The educational and technical courses in the ELT program in Turkey: Do they contribute to ICT skills? Cogent Education. 3:1. doi:10.1080/2331186X.2016.1141454

Uzun, L. (2017). Using the second life digital environment for FL education: a postmodern perspective. Teaching English with Technology, 17(2), 42-54.

Vurdien, R. (2013). Enhancing writing skills through blogging in an advanced English as a Foreign Language class in Spain. Computer Assisted Language Learning, 26(2), 126-143.

Wang, S., \& Vásquez, C. (2014). The effect of target language use in social media on intermediate-level Chinese language learners' writing performance. CALICO Journal, 31(1), p. 78-102. doi: 10.11139/cj.28.2.345-368

Wilber, D. J. (2010). Using Blogs, Wikis, and Digital Stories in the English Classroom. iWrite, Heinemann.

Yakut A.D., \& Aydın, S. (2017). An experimental study on the effects of the use of blogs on EFL reading comprehension. Innovation in Language Learning and Teaching, 11:1, 1-16. doi: 10.1080/17501229.2015.1006634

Yunus, M. M., Nordin, N., Salehi, H., Embi, M. A., \& Salehi, Z. (2013). The use of information and communication technology (ICT) in teaching ESL writing skills. English Language Teaching, 6(7), 17. https://doi.org/10.5539/elt.v6n7p1

Zhang, D. (2009). The Application of Blog in English Writing. Journal of Cambridge Studies, 4(1). 